\title{
Evaluation of the Satisfaction of Users of Weather Forecast Systems with the Service Quality Method
}

\author{
Eva Rianti \\ Universitas Putra Indonesia YPTK Padang \\ Padang, Indonesia \\ evarianti@upiyptk.ac.id
}

\author{
Syafrika Deni Rizky \\ Universitas Putra Indonesia YPTK Padang \\ Padang, Indonesia \\ deny_rizky576@yahoo.co.id
}

\author{
Fariz Haris Nugraha \\ Universitas Putra Indonesia YPTK Padang \\ Padang, Indonesia \\ farisharisnugraha92@gmail.com
}

Submitted: Feb 29, 2020

Accepted: Apr 8, 2020

Published: Apr 8, 2020

\begin{abstract}
This research was conducted to test the user's satisfaction of the weather forecast system that had been previously applied to the Teluk Bayur BMKG. The weather forecasting service at the Padang Bayur Padang BMKG has basically fulfilled the objectives of the company. However, over time, evaluation is needed so that the effectiveness of the use of the system can be known, so the system can continue to be developed. To overcome these problems, it is necessary to evaluate the performance of the system. One way is to measure user satisfaction by using Service Quality. This method is one of the techniques used to measure the level of user satisfaction with the system. Based on the results of the measurement of the quality of the weather forecast system, the results are obtained that the system user is satisfied with the system performance, but there are several indicators on the system whose performance is not fully maximized, so that there needs to be improvements and improvements of the system performance.
\end{abstract}

Keywords-Service Quality, User Satisfaction, System, Evaluation

\section{INTRODUCTION}

BMKG Teluk Bayur Padang as one of the companies that has implemented many information systems to help the work process. In the Teluk Bayur Padang BMKG there is an information system that can help manage weather data. The information system is called the Weather Forecast Information System. BMKG Teluk Bayur Padang realizes that information about weather data is very important because this information is very useful for parties involved in the decision making process, especially for shipping traffic, crossings, and so on. The system is used to help input weather data, which results will be displayed on the BMKG system.

The system has experienced many developments in terms of features and functions that will facilitate the work of its users (Nugroho, 2019). One way to optimize and improve the performance of the system is by knowing the satisfaction from the user's side. System performance can be seen from user satisfaction in using the information system. Therefore, in this study an evaluation of the user satisfaction of the Weather Forecast Information System can be seen in the system's performance. One method used to assess user satisfaction is the service quality method. This service quality method 
is one of the methods used to measure the level of user satisfaction with information systems.

\section{Literature REVIEW}

\subsection{BASIC CONCEPTS OF INFORMATION SYSTEMS}

A system can be interpreted as a collection or set of elements, components, or variables that are organized, interact with each other, interdependent with each other (Rianti, 2016). System theory says that every element of an organization is important and must receive full attention so that managers can act more effectively (Zefriyenni, 2020)

\subsubsection{Information System}

Information system is a collection of software and hardware devices and human devices that will process data using the hardware and software (Yenila, 2019)

\subsection{Service Quality}

Service Quality method is a method of measuring the quality of service most often used (Miranda, 2018). Assessing the quality of service of a service provider based on five quality dimensions that are often called Q-RATER the q-rater is:

1. Reliability, is the ability to provide the promised service reliably and accurately.

2. Assurance namely guarantees and trustworthiness owned by the company, including the knowledge and courtesy of employees in serving consumers, as well as their ability to maintain consumer confidence.

3. Tangible (physical evidence), the appearance of facilities and physical equipment used to provide or provide services, including the appearance of physical facilities, equipment, workers or communication tools.

4. Emphaty that individual attention provided by the company to consumers, including the ease of making good relationships, personal attention and understanding customer needs.

5. Responsiveness, namely the desire to help consumers and provide services quickly, namely the desire of staff to help customers and provide services with responsiveness.

\subsubsection{Service Quality Measurement}

Quality measurements in the service quality model are based on a multi-item scale designed to measure expectations on five dimensions for service quality
(Ardhyani, 2017). Service quality evaluation using the service quality model includes calculation of the difference between the values given by customers, for each pair of questions related to expectations and perceptions (R Govindaraju, 2016). Service quality scores for each pair of questions related to expectations and perceptions (Winarto, 2017).To measure the score of service satisfaction level the following formula will be used:

Service Quality Score=Perception Score-Expected Score

$$
\begin{aligned}
& \mathrm{KL}=\mathrm{P}-\mathrm{E} \\
& \mathrm{KL}: \text { Service quality score } \\
& \mathrm{P}: \text { Customer perception score } \\
& \text { E: Customer expectation score }
\end{aligned}
$$

Data obtained through service quality instruments can be used to calculate service quality gap scores at various levels in detail (Krisdayanti, 2017):

a. Item - by item analysis, for example P1 - E1, P2 - E2, and so on.

b. Dimension - by dimension analysis, for example $(\mathrm{P} 1+\mathrm{P} 2+\mathrm{P} 3+\mathrm{P} 4 / 4)-(\mathrm{E} 1-\mathrm{E} 2-\mathrm{E} 3-\mathrm{E} 4 / 4)$ where $\mathrm{P} 1$

through P4 and E1 to E5 reflect empathy questions of perception and expectations related to certain dimensions.

c. Single size calculation for servqual service quality, that is $(\mathrm{P} 1+\mathrm{P} 2++\mathrm{P} 22 / 22-(\mathrm{E} 1+\mathrm{E} 2+$ ..... $+\mathrm{E} 22$ / 22).

2.2.2 Steps for calculating the Sevice Quality method

The steps that must be taken in this Service quality method are as follows (Kuspriyono, 2017):

1. Determine the list of service attributes to be measured. To determine what attributes will be displayed, service providers can start by referring to the five main dimensions of service quality as research variables. Attributes made in the form of questions in accordance with the intent of the variables of each study.

2. Knowing the customer's opinion about these attributes. Respondents were asked to answer the question of each attribute in the list, namely how important or how much customer expectations of these attributes, how much weight is given for each service provided and how well the service performance felt by customers after using it. 
3. For each customer, determine the Servqual score for each question / attribute with the following equation:

$$
\mathrm{Si}=\mathrm{Pi}-\mathrm{Ei} ; \mathrm{i}=1,2,3, \ldots, \mathrm{n}
$$

Pi: Perceptual value given by the customer to the i question

Ei: Value of the expectation given by the customer for question I

$\mathrm{N}$ : Question number

4. For customers, add up the Servqual value obtained for each dimension, then divide the number by the number of questions or attributes on that dimension

5. For each customer, multiply the Ski value by the weight (wi) given for each dimension to get the weighted Servqual value (Sqi) for each dimension.

6. TSQ calculations for all customers are added up and divided by $\mathrm{n}$ to get the average Servqual value.

\section{PROPOSED METHOD}

In this study, the research framework can be seen from Figure 2,

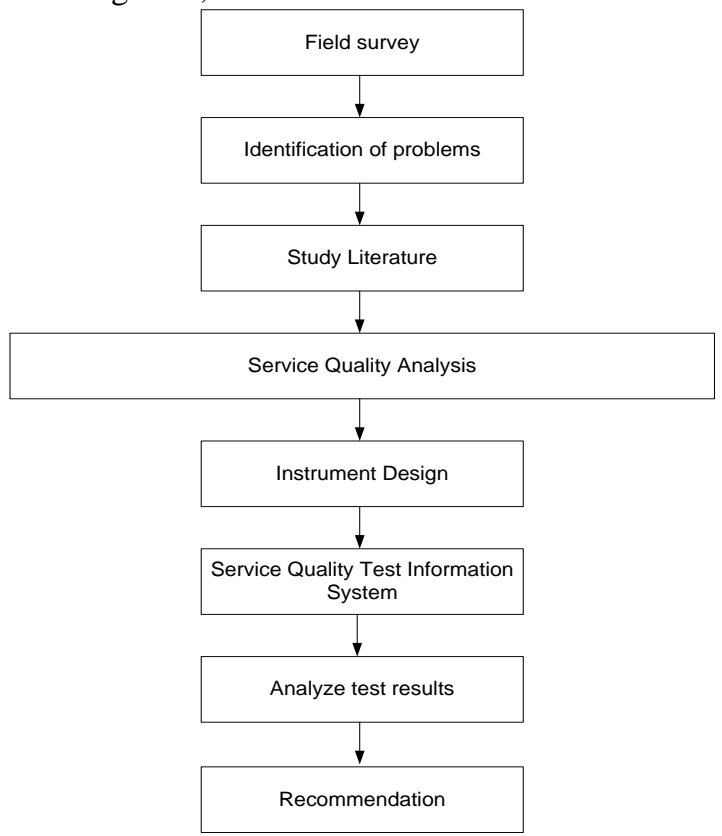

Figure 2.Service Quality Method Chart

Quotioner data analysis is performed by means of quantitative descriptive which is a direct explanation of the results of calculations using formulas on service quality.

\section{RESULT AND DISCUSSION}

\subsection{System Analysis}

System analysis is carried out aiming to find out the problems that occur in library information systems, as a basis for being able to measure the quality of a system from theories that have been studied (Dewi S Jannah, 2018)

\subsection{System Quality Measurement Using Service} quality

Service quality measurement data encompasses user expectations and perceptions of the performance of the Weather Forecast System at the Padang Bayur Padang BMKG. Assessments are grouped into 5 Iikert scales as follows:

a. For expectations:

1. Value 1: Very unimportant.

2. Value 2: Not important

3. Value 3: Neutral

4. Value 4: Penting

5. Value 5: Very Important

b. For expectations:

1. Value 1: Very unimportant.

2. Value 2: Not important

3. Value 3: Neutral

4. Value 4: Important.

5. Value 5: Very important

\subsection{Questionnaire Results}

In this study, there were 6 respondents, consisting of 6 employees in the Teluk Bayur Padang BMKG office who used the Weather Forecast System. The results of the questionnaire can be seen as follows:

\section{A Expectation Value}

The results of the questionnaire for the expected value can be seen in the following table

Table 1 .Expectation Questionnaire Results

\begin{tabular}{|c|c|l|c|c|c|c|c|}
\hline No & N & SP & P & N & TP & STP \\
\hline 1 & \multirow{2}{*}{2} & \multirow{2}{*}{$\begin{array}{l}\text { Website can } \\
\text { process data } \\
\text { well }\end{array}$} & 1 & 3 & 2 & 0 & 0 \\
\cline { 3 - 7 } & $\begin{array}{l}\text { The features } \\
\text { available on } \\
\text { the website } \\
\text { can work well }\end{array}$ & 3 & 2 & 1 & 0 & 0 \\
\hline
\end{tabular}

This is an Creative Commons License This work is licensed under a Creative Commons Attribution-NonCommercial 4.0 International License. 


\begin{tabular}{|c|c|c|c|c|c|c|c|}
\hline 3 & & $\begin{array}{l}\text { Attractive } \\
\text { table features } \\
\text { and designs }\end{array}$ & 2 & 2 & 2 & 0 & 0 \\
\hline 4 & & $\begin{array}{l}\text { The language } \\
\text { used is } \\
\text { consistent on } \\
\text { every page }\end{array}$ & 1 & 4 & 0 & 1 & 0 \\
\hline 5 & & $\begin{array}{l}\text { Information } \\
\text { from this } \\
\text { website is } \\
\text { accurate and } \\
\text { error free }\end{array}$ & 1 & 3 & 2 & 0 & 0 \\
\hline 6 & \multirow{3}{*}{ 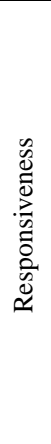 } & $\begin{array}{l}\text { Text from } \\
\text { every page can } \\
\text { be responded } \\
\text { to and read } \\
\text { clearly }\end{array}$ & 0 & 4 & 1 & 1 & 0 \\
\hline 7 & & $\begin{array}{l}\text { The choice of } \\
\text { buttons and } \\
\text { menus on the } \\
\text { website can } \\
\text { respond well }\end{array}$ & 0 & 4 & 2 & 0 & 0 \\
\hline 8 & & $\begin{array}{l}\text { The login } \\
\text { process can be } \\
\text { done quickly }\end{array}$ & 1 & 4 & 1 & 0 & 0 \\
\hline 9 & \multirow{2}{*}{ 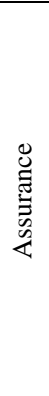 } & $\begin{array}{l}\text { Website access } \\
\text { rights can be } \\
\text { guaranteed and } \\
\text { cannot be used } \\
\text { by parties who } \\
\text { are not entitled } \\
\text { to use }\end{array}$ & 1 & 2 & 3 & 0 & 0 \\
\hline 10 & & $\begin{array}{l}\text { The process of } \\
\text { inputting data } \\
\text { can be done } \\
\text { safely and } \\
\text { smoothly }\end{array}$ & 1 & 2 & 2 & 1 & 0 \\
\hline 11 & \multirow{2}{*}{ 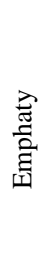 } & $\begin{array}{l}\text { The operator } \\
\text { can see the } \\
\text { time and date } \\
\text { of use of the } \\
\text { website }\end{array}$ & 0 & 4 & 2 & 0 & 0 \\
\hline 12 & & $\begin{array}{l}\text { Users can be } \\
\text { interpreted by } \\
\text { operators }\end{array}$ & 0 & 4 & 2 & 0 & 0 \\
\hline 13 & 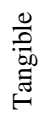 & $\begin{array}{l}\text { System hint } \\
\text { service for } \\
\text { new users }\end{array}$ & 0 & 3 & 3 & 0 & 0 \\
\hline \multicolumn{3}{|c|}{ amount } & 11 & 41 & 23 & 3 & 0 \\
\hline
\end{tabular}

B Perception Value

The results of the questionnaire for the value of perception can be seen in the following table:

Table 2 .Perception Value Questionnaire Results

\begin{tabular}{|c|c|l|l|l|l|l|c|}
\hline $\begin{array}{c}\text { N } \\
\mathrm{o}\end{array}$ & $\begin{array}{c}\text { Dimention Of } \\
\text { Quality }\end{array}$ & Indicator & $\begin{array}{c}\mathrm{S} \\
\mathrm{P}\end{array}$ & $\mathrm{P}$ & $\mathrm{N}$ & $\begin{array}{c}\mathrm{T} \\
\mathrm{P}\end{array}$ & $\begin{array}{c}\text { ST } \\
\mathrm{P}\end{array}$ \\
\hline
\end{tabular}

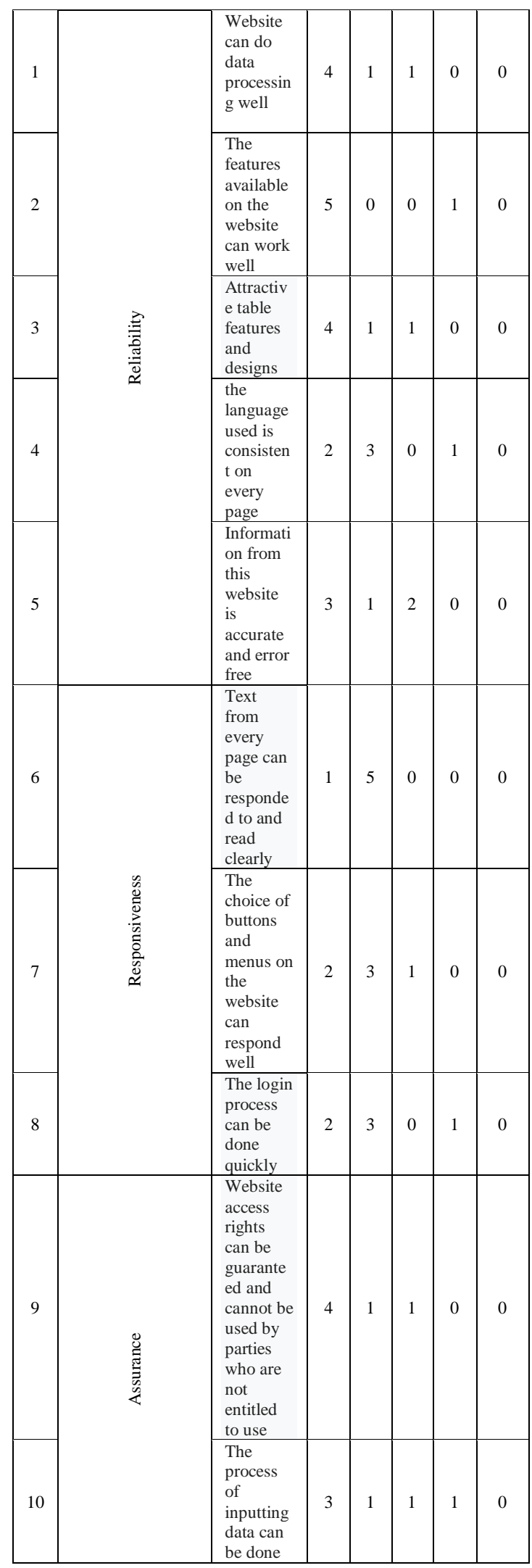

This is an Creative Commons License This work is licensed under a Creative Commons Attribution-NonCommercial 4.0 International License. 


\begin{tabular}{|c|c|c|c|c|c|c|c|}
\hline & & $\begin{array}{l}\text { safely } \\
\text { and } \\
\text { smoothly }\end{array}$ & & & & & \\
\hline 11 & \multirow[t]{2}{*}{ 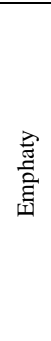 } & $\begin{array}{l}\text { Operator } \\
\text { s can see } \\
\text { the time } \\
\text { and date } \\
\text { of } \\
\text { website } \\
\text { usage }\end{array}$ & 1 & 4 & 1 & 0 & 0 \\
\hline 12 & & $\begin{array}{l}\text { Users } \\
\text { can be } \\
\text { interprete } \\
\mathrm{d} \text { by } \\
\text { operators }\end{array}$ & 1 & 4 & 1 & 0 & 0 \\
\hline 13 & 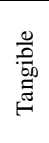 & $\begin{array}{l}\text { System } \\
\text { hint } \\
\text { service } \\
\text { for new } \\
\text { users }\end{array}$ & 2 & 2 & 2 & 0 & 0 \\
\hline \multicolumn{3}{|c|}{ Jumlah } & $\begin{array}{l}3 \\
4\end{array}$ & $\begin{array}{l}2 \\
9\end{array}$ & $\begin{array}{l}1 \\
1\end{array}$ & 4 & 0 \\
\hline
\end{tabular}

\section{Expectation Value}

1. Calculates the total score of each indicator.

Carried out by: Total score $=\mathrm{P} 5 \times 5+\mathrm{P} 4 \times 4+\mathrm{P} 3 \times 3$ $+\mathrm{P} 2 \times 2+\mathrm{P} 1 \times 1$.

Where the results are as follows:

Indicator $1=(5 \times 4)+(4 \times 1)+(3 \times 1)+$ $(2 \times 0)+(1 \times 0)=27$

Indicator $2=(5 \times 5)+(4 \times 0)+(3 \times 0)+$ $(2 \times 1)+(1 \times 0)=27$

Indicator $3=(5 \times 4)+(4 \times 2)+(3 \times 2)+$ $(2 \times 0)+(1 \times 0)=27$

Indicator $4=(5 \times 2)+(4 \times 3)+(3 \times 0)+$ $(2 \times 1)+(1 \times 0)=24$

Indicator $5=(5 \times 3)+(4 \times 1)+(3 \times 2)+$ $(2 \times 0)+(1 \times 0)=25$

Indicator $6=(5 \times 1)+(4 \times 5)+(3 \times 0)+$ $(2 \times 0)+(1 \times 0)=25$

Indicator $7=(5 \times 2)+(4 \times 3)+(3 \times 1)+$ $(2 \times 0)+(1 \times 0)=25$

Indicator $8=(5 \times 2)+(4 \times 3)+(3 \times 0)+$ $(2 \times 1)+(1 \times 0)=24$

Indicator $9=(5 \times 4)+(4 \times 1)+(3 \times 1)+$ $(2 \times 0)+(1 \times 0)=27$

Indicator $10=(5 \times 3)+(4 \times 1)+(3 \times 1)+$ $(2 \times 1)+(1 \times 0)=24$

Indicator $11=(5 \times 1)+(4 \times 4)+(3 \times 1)+$ $(2 \times 0)+(1 \times 0)=24$

Indicator $12=(5 \times 1)+(4 \times 4)+(3 \times 1)+$ $(2 \times 0)+(1 \times 0)=24$

Indicator $13=(5 \times 2)+(4 \times 2)+(3 \times 2)$

$+(2 \times 0)+(1 \times 0)=24$

2. Divide the total score by the number of respondents Done by: hope value = total score: number of respondents. Expectation value indicates the value of service expected by the user on the performance of the Weather Forecast System at BMKG Teluk Bayur Padang. The expected value of each indicator will be presented in the following table:

Table 3. User Expectation Value

\begin{tabular}{|c|c|c|c|c|c|c|c|c|}
\hline \multirow{3}{*}{$\begin{array}{l}\mathrm{N} \\
\mathrm{o}\end{array}$} & \multirow{3}{*}{ Indicator } & \multicolumn{7}{|c|}{ Expectation } \\
\hline & & 5 & 4 & 3 & 2 & 1 & & \\
\hline & & है & 2 & z & 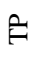 & 空 & $\stackrel{0}{\circ}$ & 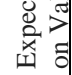 \\
\hline 1 & $\begin{array}{l}\text { Website } \\
\text { can do } \\
\text { data } \\
\text { processin } \\
\text { g well }\end{array}$ & 4 & 1 & 1 & 0 & 0 & 27 & $\begin{array}{c}4,5 \\
0\end{array}$ \\
\hline 2 & $\begin{array}{l}\text { The } \\
\text { features } \\
\text { available } \\
\text { on the } \\
\text { website } \\
\text { can work } \\
\text { well }\end{array}$ & 5 & 0 & 0 & 1 & 0 & 27 & $\begin{array}{c}4,5 \\
0\end{array}$ \\
\hline 3 & $\begin{array}{l}\text { Attractive } \\
\text { table } \\
\text { features } \\
\text { and } \\
\text { designs }\end{array}$ & 4 & 1 & 1 & 0 & 0 & 27 & $\begin{array}{c}4,5 \\
0\end{array}$ \\
\hline 4 & $\begin{array}{l}\text { the } \\
\text { language } \\
\text { used is } \\
\text { consistent } \\
\text { on every } \\
\text { page }\end{array}$ & 2 & 3 & 0 & 1 & 0 & 24 & $\begin{array}{c}4,0 \\
0\end{array}$ \\
\hline 5 & $\begin{array}{l}\text { Informati } \\
\text { on from } \\
\text { this } \\
\text { website is } \\
\text { accurate } \\
\text { and error } \\
\text { free }\end{array}$ & 3 & 1 & 2 & 0 & 0 & 25 & $\begin{array}{c}4,1 \\
7\end{array}$ \\
\hline 6 & $\begin{array}{l}\text { Text from } \\
\text { every } \\
\text { page can } \\
\text { be } \\
\text { responde } \\
\text { d to and } \\
\text { read } \\
\text { clearly }\end{array}$ & 1 & 5 & 0 & 0 & 0 & 25 & $\begin{array}{c}4,1 \\
7\end{array}$ \\
\hline 7 & $\begin{array}{l}\text { The } \\
\text { choice of } \\
\text { buttons } \\
\text { and } \\
\text { menus on } \\
\text { the } \\
\text { website } \\
\text { can } \\
\text { respond } \\
\text { well }\end{array}$ & 2 & 3 & 1 & 0 & 0 & 25 & $\begin{array}{c}4,1 \\
7\end{array}$ \\
\hline 8 & $\begin{array}{l}\text { The login } \\
\text { process } \\
\text { can be } \\
\text { done } \\
\text { quickly }\end{array}$ & 2 & 3 & 0 & 1 & 0 & 24 & $\begin{array}{c}4,0 \\
0\end{array}$ \\
\hline
\end{tabular}




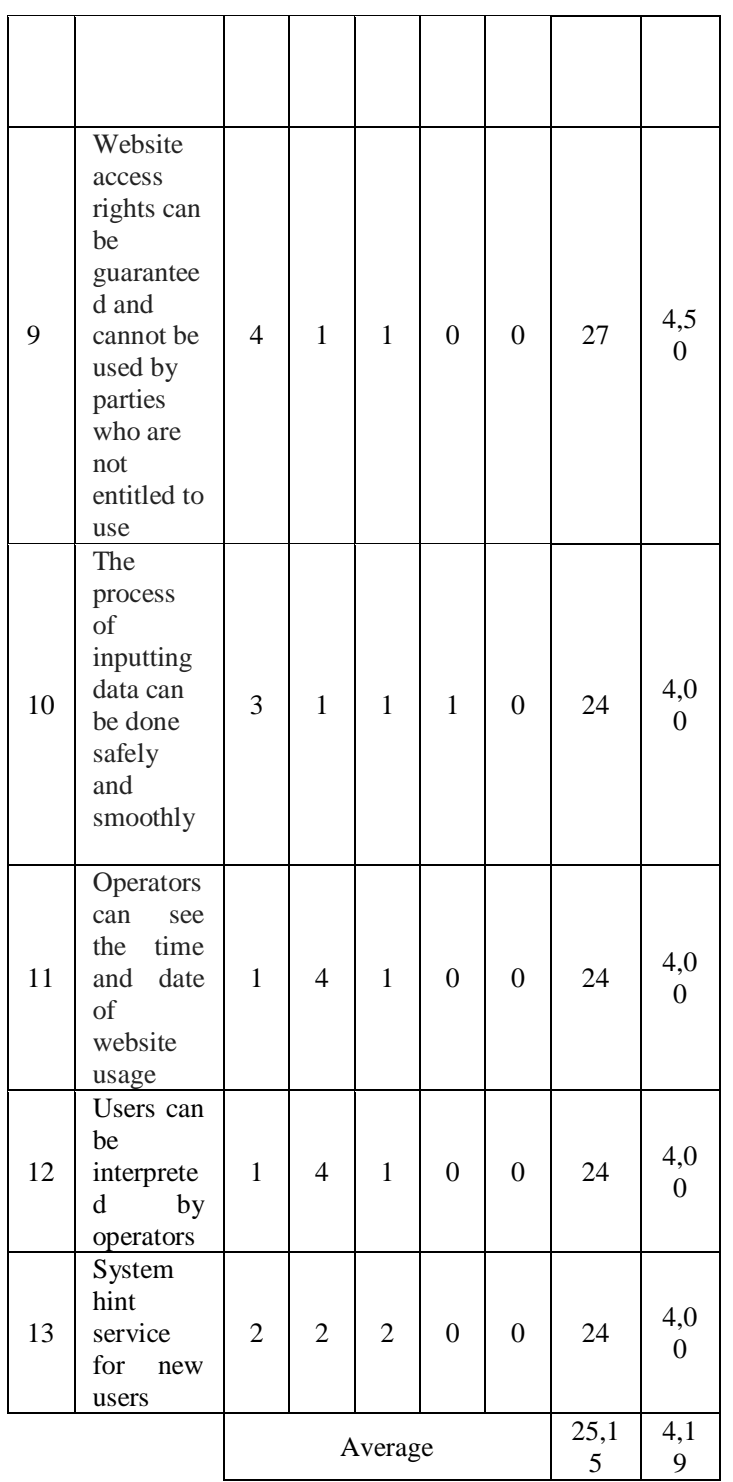

\section{D.Perception Value}

1. Calculate the total score of each indicator.

Done by means of a total score $=\mathrm{P} 5 \mathrm{X} 5+\mathrm{P} 4 \mathrm{x} 4+$ $\mathrm{P} 3 \mathrm{x} 3+\mathrm{P} 2 \mathrm{x} 2+\mathrm{P} 1 \mathrm{x} 1$

Where the results are as follows:

Indicator $1=(5 \times 1)+(4 \times 3)+(3 \times 2)+(2 \times 0)+$ $(1 \times 0)=23$

Indicator $2=(5 \times 3)+(4 \times 2)+(3 \times 1)+(2 \times 0)+$ $(1 \times 0)=26$

Indicator $3=(5 \times 2)+(4 \times 2)+(3 \times 2)+(2 \times 0)+$ $(1 \times 0)=24$
Indicator $4=(5 \times 1)+(4 \times 4)+(3 \times 0)+(2 \times 1)+$ $(1 \times 0)=23$

Indicator $5=(5 \times 1)+(4 \times 3)+(3 \times 2)+(2 \times 0)+$ $(1 \times 0)=23$

Indicator $6=(5 \times 0)+(4 \times 4)+(3 \times 1)+(2 \times 1)+$ $(1 \times 0)=21$

Indicator $7=(5 \times 0)+(4 \times 4)+(3 \times 2)+(2 \times 0)+$ $(1 \times 0)=22$

Indicator $8=(5 \times 1)+(4 \times 4)+(3 \times 1)+(2 \times 0)+$ $(1 \times 0)=24$

Indicator $9=(5 \times 1)+(4 \times 2)+(3 \times 3)+(2 \times 0)+$ $(1 \times 0)=22$

Indicator $10=(5 \times 1)+(4 \times 2)+(3 \times 2)+(2 \times 1)$ $+(1 \times 0)=21$

Indicator $11=(5 \times 0)+(4 \times 4)+(3 \times 2)+(2 \times 0)$ $+(1 \times 0)=22$

Indicator $12=(5 \times 0)+(4 \times 4)+(3 \times 2)+(2 \times 0)$ $+(1 \times 0)=22$

Indicator $13=(5 \times 1)+(4 \times 3)+(3 \times 3)+(2 \times 0)$ $+(1 \times 0)=21$

2. Divide the total score by the number of respondents

Done with the formula: expectation value $=$ total score: number of respondents

Table 4. User Perception Value

\begin{tabular}{|c|c|c|c|c|c|c|c|c|}
\hline \multirow{3}{*}{ No } & \multirow{3}{*}{ Indikator } & \multicolumn{7}{|c|}{ Persepsi } \\
\hline & & 5 & 4 & 3 & 2 & 1 & & \\
\hline & & $\hat{\sigma}$ & $\mathbf{P}$ & $\mathbf{N}$ & 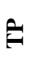 & 空 & $\stackrel{0}{\oplus}$ & ${ }_{\overline{0}}^{\overrightarrow{0}}>$ \\
\hline 1 & $\begin{array}{l}\text { Website can } \\
\text { do data } \\
\text { processing } \\
\text { well }\end{array}$ & 1 & 3 & 2 & 0 & 0 & 23 & 3,83 \\
\hline 2 & $\begin{array}{l}\text { The features } \\
\text { available on } \\
\text { the web can } \\
\text { work well }\end{array}$ & 3 & 2 & 1 & 0 & 0 & 26 & 4,33 \\
\hline 3 & $\begin{array}{l}\text { Attractive } \\
\text { table } \\
\text { features and } \\
\text { designs }\end{array}$ & 2 & 2 & 2 & 0 & 0 & 24 & 4,00 \\
\hline 4 & $\begin{array}{l}\text { the } \\
\text { language } \\
\text { used is } \\
\text { consistent } \\
\text { on every } \\
\text { page }\end{array}$ & 1 & 4 & 0 & 1 & 0 & 23 & 3,83 \\
\hline 5 & $\begin{array}{l}\text { Information } \\
\text { from this } \\
\text { website is } \\
\text { accurate and } \\
\text { error free }\end{array}$ & 1 & 3 & 2 & 0 & 0 & 23 & 3,83 \\
\hline 6 & $\begin{array}{l}\text { Text from } \\
\text { every page } \\
\text { can be } \\
\text { responded } \\
\text { to and read } \\
\text { clearly }\end{array}$ & 0 & 4 & 1 & 1 & 0 & 21 & 3,50 \\
\hline
\end{tabular}




\begin{tabular}{|c|c|c|c|c|c|c|c|c|}
\hline 7 & $\begin{array}{l}\text { The choice } \\
\text { of buttons } \\
\text { and menus } \\
\text { on the } \\
\text { website can } \\
\text { respond } \\
\text { well }\end{array}$ & 0 & 4 & 2 & 0 & 0 & 22 & 3,67 \\
\hline 8 & $\begin{array}{l}\text { The login } \\
\text { process can } \\
\text { be done } \\
\text { quickly }\end{array}$ & 1 & 4 & 1 & 0 & 0 & 24 & 4,00 \\
\hline 9 & $\begin{array}{l}\text { Website } \\
\text { access } \\
\text { rights can } \\
\text { be } \\
\text { guaranteed } \\
\text { and cannot } \\
\text { be used by } \\
\text { parties who } \\
\text { are not } \\
\text { entitled to } \\
\text { use }\end{array}$ & 1 & 2 & 3 & 0 & 0 & 22 & 3,67 \\
\hline 10 & $\begin{array}{l}\text { The process } \\
\text { of inputting } \\
\text { data can be } \\
\text { done safely } \\
\text { and } \\
\text { smoothly }\end{array}$ & 1 & 2 & 2 & 1 & 0 & 21 & 3,50 \\
\hline 11 & $\begin{array}{l}\text { Operators } \\
\text { can see the } \\
\text { time and } \\
\text { date of } \\
\text { website } \\
\text { usage }\end{array}$ & 0 & 4 & 2 & 0 & 0 & 22 & 3,67 \\
\hline 12 & $\begin{array}{l}\text { Users can } \\
\text { be } \\
\text { interpreted } \\
\text { by operators }\end{array}$ & 0 & 4 & 2 & 0 & 0 & 22 & 3,67 \\
\hline 13 & $\begin{array}{l}\text { System hint } \\
\text { service for } \\
\text { new users }\end{array}$ & 0 & 3 & 3 & 0 & 0 & 21 & 3,50 \\
\hline & & \multicolumn{5}{|c|}{ Average } & 22,62 & 3,77 \\
\hline
\end{tabular}

3. Calculate Service Quality Score Servqual Score $($ Gap Score $)=$ Perception Value - Expectation Value

Where the results are as follows:

Gap Score $1=3,83-4,50=-0,67$

Gap Score $2=4,33-4,50=-0,17$

Gap Score $3=4,00-4,50=-0,50$

Gap Score $4=3,83-4,00=-0,17$

Gap Score $5=3,83-4,17=-0,34$

Gap Score 6 $=3,50-4,17=-0,67$

Gap Score $7=3,67-4,17=-0,50$

Gap Score $8=4,00-4,00=0,00$

Gap Score $9=3,67-4,50=-0,83$

Gap Score $10=3,50-4,00=-0,50$

Gap Score $11=3,67-4,00=-0,33$

GapSkor $12=3,67-4,00=-0,33$

Gap Score $13=3,50-4,50=-0,50$

Table.5 Service quality scores User Satisfaction Rating

\begin{tabular}{|c|c|c|c|c|}
\hline No & Indicator & 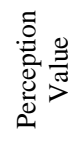 & 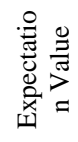 & Gap Score \\
\hline 1 & $\begin{array}{l}\text { Website can do } \\
\text { data processing } \\
\text { well }\end{array}$ & 3,83 & 4,50 & $-0,67$ \\
\hline 2 & $\begin{array}{l}\text { The features } \\
\text { available on the } \\
\text { website can work } \\
\text { well }\end{array}$ & 4,33 & 4,50 & $-0,17$ \\
\hline 3 & $\begin{array}{l}\text { Attractive table } \\
\text { features and } \\
\text { designs }\end{array}$ & 4,00 & 4,50 & $-0,50$ \\
\hline 4 & $\begin{array}{l}\text { the language used } \\
\text { is consistent on } \\
\text { every page }\end{array}$ & 3,83 & 4,00 & $-0,17$ \\
\hline 5 & $\begin{array}{l}\text { Information from } \\
\text { this website is } \\
\text { accurate and error } \\
\text { free }\end{array}$ & 3,83 & 4,17 & $-0,34$ \\
\hline 6 & $\begin{array}{l}\text { Text from every } \\
\text { page can be } \\
\text { responded to and } \\
\text { read clearly }\end{array}$ & 3,50 & 4,17 & $-0,67$ \\
\hline 7 & $\begin{array}{l}\text { The choice of } \\
\text { buttons and menus } \\
\text { on the website can } \\
\text { respond well }\end{array}$ & 3,67 & 4,17 & $-0,50$ \\
\hline 8 & $\begin{array}{l}\text { The login process } \\
\text { can be done } \\
\text { quickly }\end{array}$ & 4,00 & 4,00 & 0,00 \\
\hline 9 & $\begin{array}{l}\text { Website access } \\
\text { rights can be } \\
\text { guaranteed and } \\
\text { cannot be used by } \\
\text { parties who are not } \\
\text { entitled to use }\end{array}$ & 3,67 & 4,50 & $-0,83$ \\
\hline 10 & $\begin{array}{l}\text { The process of } \\
\text { entering data can } \\
\text { be done safely and } \\
\text { smoothly }\end{array}$ & 3,50 & 4,00 & $-0,50$ \\
\hline 11 & $\begin{array}{l}\text { Operators can see } \\
\text { the time and date } \\
\text { of website usage }\end{array}$ & 3,67 & 4,00 & $-0,33$ \\
\hline 12 & $\begin{array}{l}\text { Users can be } \\
\text { interpreted by } \\
\text { operators }\end{array}$ & 3,67 & 4,00 & $-0,33$ \\
\hline 13 & $\begin{array}{l}\text { System hint } \\
\text { service for new } \\
\text { users }\end{array}$ & 3,50 & 4,00 & $-0,50$ \\
\hline & amount & 49,00 & 54,51 & $-5,51$ \\
\hline \multicolumn{4}{|c|}{ Gap Value Maximum Score } & 0,00 \\
\hline \multicolumn{4}{|c|}{ Gap Value Minimum Score } & $-0,83$ \\
\hline
\end{tabular}

\section{E. Cartesian diagram}

In this study there are two variables represented by the letters $\mathrm{X}$ and $\mathrm{Y}$, where $\mathrm{X}$ is the level of user perception of the performance provided by the system, while $\mathrm{Y}$ is the level of user expectations of 
the performance provided by the system. Furthermore, the levels of these elements are elaborated and divided into 4 parts into a Cartesian diagram

The formula: $\dot{\mathrm{X}}=\Sigma \mathrm{Xi}: \mathrm{K}$ and $\dot{\mathrm{Y}}=\Sigma \mathrm{Yi}: \mathrm{K}$

$\dot{\mathrm{X}}=$ average score of implementation level

$\dot{\mathrm{Y}}=$ average score of importance

$\mathrm{K}=$ number of factors / attributes

Where the results are as follows

1. For User Perception

$\dot{\mathrm{X}}=49.00: 6=3.77$

2. For User Expectations

$\dot{\mathrm{Y}}=54.51: 6=4.19$

From the above calculation, it is obtained that the value of $\mathrm{X}=$ average score of the perception level and $\mathrm{Y}=$ the average score of the expectation level presented in the following Table.6:

Table.6 Values $\dot{X}$ and Cart Cartesian diagrams

\begin{tabular}{|c|c|c|c|}
\hline No & Variabel & Information & score \\
\hline 1 & $\dot{\mathrm{X}}$ & $\begin{array}{c}\text { Implementation level } \\
\text { (user perception) }\end{array}$ & 3,77 \\
\hline 2 & $\dot{\mathrm{Y}}$ & $\begin{array}{c}\text { Level of importance } \\
\text { (user expectations) }\end{array}$ & 4,19 \\
\hline
\end{tabular}

This diagram consists of four quadrants: the first quadrant is located in the upper left, the second quadrant in the upper right, the third quadrant in the lower left, and the fourth quadrant in the lower right. Each variable in the quadrant can be explained as follows:

1. Quadrant I

This is an area that contains factors that are considered important by the user but in reality these factors are not in line with what the user expects (the level of satisfaction obtained is still very low). The variables included in this quadrant must be increased.

2. Quadrant II

This is an area that contains factors that are considered important by users and factors that are considered by users to be in accordance with what they feel so that the level of satisfaction is relatively higher. The variables included in this quadrant must be maintained because all of these variables make the indicator superior to the user.

3. Quadrant III

This is an area where the factors that are considered less important by the user and in fact the performance is not too special. The increase in the variables included in this quadrant can be reconsidered because the effect on the benefits felt by the user is very small.

4. Quadrant IV

This is an area that contains factors that are considered less important by the user and are overly excessive. The variables included in this quadrant can be reduced.

Figure 1: Cartesian Diagram of Satisfaction Assessment

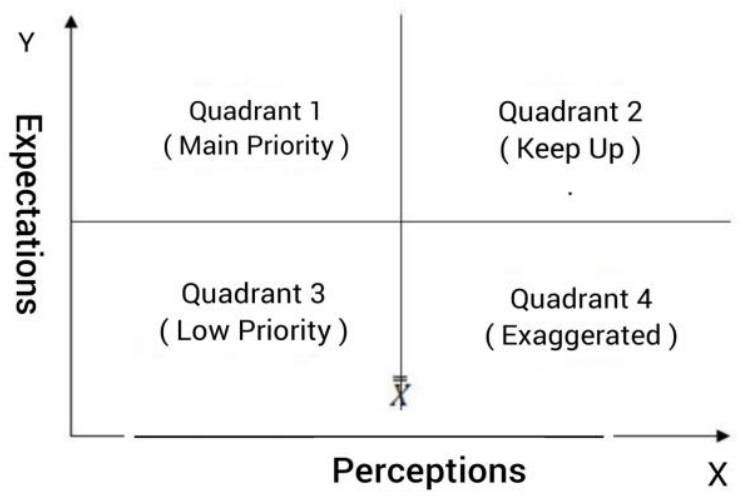

Figure.2 Matrix of Expectations and Perceptions

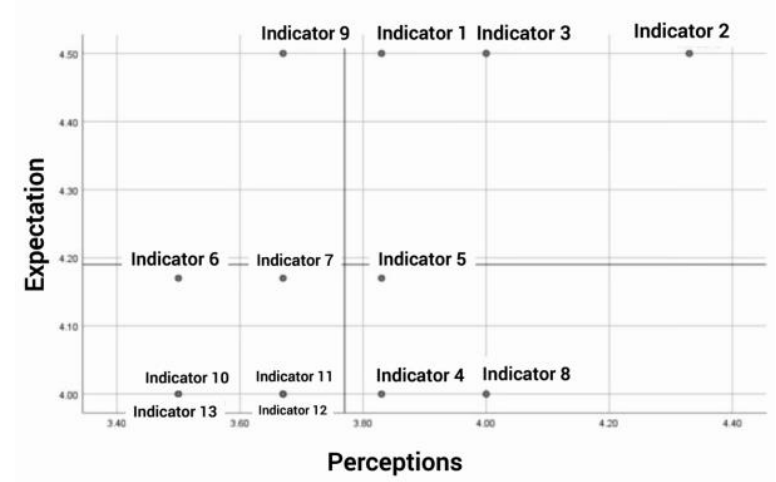

F. Distribution and percentage of users' perceptions of service

Table.7 Distribution and Percentage of User Satisfaction

\begin{tabular}{|l|c|c|}
\hline \multicolumn{1}{|c|}{$\begin{array}{c}\text { Satisfaction } \\
\text { Response }\end{array}$} & $\begin{array}{c}\text { Distributio } \\
\mathbf{n}\end{array}$ & $\begin{array}{c}\text { Percentag } \\
\mathbf{e}(\mathbf{\%})\end{array}$ \\
\hline 5 = Very satisfied & 11 & 14,1 \\
\hline 4 = Satisfied & 41 & 52,6 \\
\hline 3 = Neutral & 23 & 29,5 \\
\hline 2 = Not satisfied & 3 & 3,8 \\
\hline $\begin{array}{l}\text { 1 = Very } \\
\text { Dissatisfied }\end{array}$ & 0 & 0,0 \\
\hline Total & 78 & 100 \\
\hline
\end{tabular}

G.Quality Performance of Service Attributes

From the data obtained that the average servqual score is -0.42 meaning that the gap score between 
user expectations and what users feel is negative. This means that the average new user expectations are met by the Weather Forecast System with a score of 0.42 .

The gap score of each indicator and the average gap score of the user satisfaction assessment by the Weather Forecast System will be shown in the following Table.8:

\begin{tabular}{|c|c|c|c|}
\hline No & Indicator & Gap Score & $\begin{array}{c}\text { Gap } \\
\text { Average }\end{array}$ \\
\hline 1 & $\begin{array}{l}\text { Website can do data } \\
\text { processing well }\end{array}$ & $-0,67$ & \multirow{13}{*}{$-0,42$} \\
\hline 2 & $\begin{array}{l}\text { The features available on } \\
\text { the website can work well }\end{array}$ & $-0,17$ & \\
\hline 3 & $\begin{array}{l}\text { Attractive table features } \\
\text { and designs }\end{array}$ & $-0,50$ & \\
\hline 4 & $\begin{array}{l}\text { the language used is } \\
\text { consistent on every page }\end{array}$ & $-0,17$ & \\
\hline 5 & $\begin{array}{l}\text { Information from this } \\
\text { website is accurate and } \\
\text { error free }\end{array}$ & $-0,34$ & \\
\hline 6 & $\begin{array}{l}\text { Text from every page can } \\
\text { be responded to and read } \\
\text { clearly }\end{array}$ & $-0,67$ & \\
\hline 7 & $\begin{array}{l}\text { The choice of buttons and } \\
\text { menus on the website can } \\
\text { respond well }\end{array}$ & $-0,50$ & \\
\hline 8 & $\begin{array}{l}\text { The login process can be } \\
\text { done quickly }\end{array}$ & 0,00 & \\
\hline 9 & $\begin{array}{l}\text { Website access rights can } \\
\text { be guaranteed and cannot } \\
\text { be used by parties who are } \\
\text { not entitled to use }\end{array}$ & $-0,83$ & \\
\hline 10 & $\begin{array}{l}\text { The process of inputting } \\
\text { data can be done safely and } \\
\text { smoothly }\end{array}$ & $-0,50$ & \\
\hline 11 & $\begin{array}{l}\text { Operators can see the time } \\
\text { and date of website usage }\end{array}$ & $-0,33$ & \\
\hline 12 & $\begin{array}{l}\text { Users can be interpreted by } \\
\text { operators }\end{array}$ & $-0,33$ & \\
\hline 13 & $\begin{array}{l}\text { System hint service for } \\
\text { new users }\end{array}$ & $-0,50$ & \\
\hline
\end{tabular}

H. Cartesian diagram analysis

1. Quadrant I (Top Priority)

The indicators that are in this quadrant are considered very important by the user but the system performance is not satisfactory. Indicators in this quadrant become the main priority for immediate improvement and improved performance. The indicators in quadrant 1 are as follows:

a. Indicator 9: Website access rights can be guaranteed and cannot be used by parties who are not entitled to use

\section{Quadrant II (Maintain Performance)}

The indicators in this quadrant are considered very important by the user and the performance of the system is very satisfying. The indicators included in this quadrant must be maintained because the performance indicators are considered superior to users.

a. Indicator 1: Website can do data processing well b. Indicator 2: The features on the website can work well

c. Indicator 3: Attractive table designs and features 3. Quadrant III (Low Priority)

The indicators in this quadrant are considered not too important for the user and the performance of the system is not satisfactory. The increase of the indicators in this quadrant can be reconsidered because the effect on the benefits felt by the user is very small. The indicators in quadrant III are as follows:

a. Indicator 6: The writing of the text on each page can be responded to and read clearly

b. Indicator 7: The choice of buttons and menus on the website can respond well

c. Indicator 10: The process of inputting data can be done safely and smoothly

d. Indicator 11: Operators can see the time and date of website usage

e. Indicator 12: Users can be interpreted by operators

f. Indicator 13: Service hints on the system for new users

4. Quadrant IV (Excessive)

The indicators in this quadrant are considered not too important by the user but the system is satisfactory. Performance indicators in this quadrant may be reduced because the user considers not too important. The indicators in this quadrant are as follows:

a. Indicator 4: The language used is consistent on every page

b. Indicator 5: Information from this website is accurate and error free

c. Indicator 8: Login process can be done quickly

\section{CONClusionand Suggestion}

\section{A. Conclusion}

Processing data taken from the results of the questionnaire found that $52.6 \%$ of system users feel satisfied with the performance of the system and $14.1 \%$ of users rate very satisfied, this shows that generally system users feel satisfied with the current system performance. 
Based on the evaluation that has been done, the following conclusions are obtained:

1. From the Cartesian diagram image that has been made before then the results are found:

\section{In quadrant I, contain indicator question 9}

2. In quadrant II, contain indicator questions 1, 2, and 3

3. In quadrant III, contain indicators questions $6,7,10,11,12$, and 13

4. In quadrant $I V$, contain indicators questions 4, 5, and 8

2. From the evaluation results of the Cartesian Diagram we can find out that the indicator that is in quadrant 1 is the indicator question 9, namely website access rights can be guaranteed and cannot be used by unauthorized parties, a major priority in improving system performance, due to the performance of the indicator this is considered important by the user of the system but in reality this indicator is not in line with what is expected by the user, as for othindicators that need to be considered to improve performance is the indicator that is in the third quadrant, because the benefits felt by the user to the system feels very small, As for the indicators are:

a. Indicator 6: The writing on each page is responded to and read clearly

b. Indicator 7: Choice of buttons and menus on the website can respond well

c. Indicator 10: The data input process is carried out safely and smoothly

d. Indicator 11: Operators can see the time when using the website

e. Indicator 12: Users can be interpreted by operators

f. Indicator 13: Service hints on the system for new users

3. Based on the results of measuring the quality of the system using the Service
Quality method it can be concluded that this method is quite effective to be used in the calculation of the system quality assessment, because a company can know the level of system performance and the level of needs of users so that system performance can be improved even better.

\section{B. Suggestion}

Based on the results of research conducted, suggestions that can be given include:

1. It is expected that the IT team at the company will be able to improve and improve the performance of the system based on the results of the evaluation given previously, especially on the indicators in quadrants 1 and 3.

2. Improving system performance can be done by improving the quality of service on each indicator and adding features that it feels need to be added in order to improve system performance.

3. Evaluation of user satisfaction is expected to be carried out regularly and continuously so that it can be known what indicators of service quality need to be improved, because the hopes and perceptions of users are increasingly developing over time.

\section{REFERENCES}

Ardhyani, I. (2017). Pengukuran Kualitas LAYANAN DENGAN HIGHER EDUCATION SERVICE QuALITY (HIEDQUAL). TEKNIKA: ENGINEERING AND SAINS JOURNAL, 25-32.

Dewi S Jannah, J. (2018). Analisis dan Perancangan Sistem Informasi Manajemen Aset Tetap Pada PT. Metis Teknologi Corporindo. JUST IT: Jurnal Sistem Informasi, Teknologi Informasi dan Komputer , 81-91.

Hashem, H. F. (2009). Adaptive technique for human face detection using HSV color space and neural networks. National Radio Science Conference. IEEE.

Krisdayanti. (2017). Pengaruh Kualitas Layanan Dan Kepuasan Konsumen Terhadap Loyalitas Konsumen Pada Minimarket Kertapati Jaya 
Indah Palembang.[Skripsi]. Doctoral Dissertation UIN Raden Fatah Palembang .

Kuspriyono. (2017). Pengaruh Kualitas Informasi Web dan Kualitas Layanan Online Terhadap Citra Bukalapak. com. Junal Perspektif , 5662.

Miranda, S. (2018). Perceived Service Quality and Customer Satisfaction : A Fuzzy set QCA Approach in the Railway sector. Journal of Bussiness Research, 371-377.

Nugroho, S. (2019). Analisis Iklim Ekstrim Untuk Deteksi Perubahan Iklim di Sumatera Barat. Jurnal Ilmu Lingkungan, 7-14.

Pittsburgh, U. o. (2019, February 18). University of Library System. Retrieved from Citation Styles: APA, MLA, Chicago, Turabian, IEEE: APA 6th Edition: https://pitt.libguides.com/c.php?g=12108\&p= 64730

R Govindaraju, W. (2016). Pengembangan Model Evaluasi Kualitas Layanan Sistem EGovernment. Journal of Technology Management, 196-205.

Rianti, E. (2016). Support, Designing Aplication Decision Support System for Science Olympics Participant Election In SMPN Sijunjung Using Analitical Hierarky Proses. Jurnal Sains dan Informatika : Research Of Science and Informatic , 22-26.

Winarto, W. (2017). Persepsi Kualitas Layanan Warung Internet di Kota Medan. Jurnal Ilmiah METHONOMI , 107-115.

Yenila, F. (2019). Analisa Sistem Informasi Pemeliharaan Prasarana Jalan dan Jembaran Dinas Pekerjaan Umum. Jurnal Teknologi, 21-25.

Zefriyenni. (2020). Reclamation Tax Calculating at Revenue Service, Regional Financial asset Management (DPPKAD) Pariaman City. Jurnal KomtekInfo , 41-46. 